\title{
An Evaluation of Five Pole-Bean Varieties for a Breeding Program
}

\author{
Oscar D. Ramírez and Raúl Abrams'
}

\section{INTRODUCTION}

Snap beans are one of the most popular vegetables consumed in Puerto Rico. Practically all the stringless beans consumed in the Island are imported as canned beans. During the fiscal year of 1957-58 the total importation of canned snap beans amounted to $3,053,335$ pounds with a value of $\$ 372,910(1)^{2}$. A very small amount is cultivated during the winter months with seed imported from the United States. We feel there is a need to develop a stringless strain of bean adapted to the conditions of Puerto Rico.

In starting a breeding program with the purpose of developing a stringless strain of bean the initial phase consists of assembling and evaluating as well as possible the best currently available material. A knowledge of productiveness, quality, flavor, and disease and insect resistance is needed before selecting the material to be used in our program. To obtain some of this information a bean-variety trial was conducted.

\section{MATEIRIALS AND METHODS}

The five pole-bean varieties used in this trial are planted commercially in the United States. They are characterized by good yield, excellent quality, and processing appearance and flavor. A brief description of the varieties is as follows (2):

Kentucky 191 is a leading variety for shipping and for the local market, also for home gardens. The plants are vigorous, productive, and resistant to some strains of rust. The pods are long, smooth, oval, and medium darkgreen. The seed are white.

Florigreen is a new variety in the Kentucky 191 class. The plants are vigorous, very productive, and early-maturing. Florigreen is resistant to common bean and southern bean mosaics and also has shown resistance to bean rust. The pods are long, wide, thick, flat, and somewhat rough. The seed are white.

Blue Lake 92 is an early strain in the stringless Blue Lake class. The plant is resistant to common bean mosaic and some strains of bean rust. The pods are very dark-green, round, straight, meaty, and stringless at all stages, and slow in seed development. The seed are white.

1 Assistant Plant Breeders, Agricultural Experiment Station, University of Puerto Rico, Río Piedras and Isabela, $\mathbf{P}$. R.

2 Ilalic numbers in parentheses refer to Literature Cited, p. 34. 
Blue Lake 228 is a strain used for early picking. The plants are vigorous, productive, and resistant to common bean and southern bean mosaics. The variety also has resistance to some strains of bean rust. The pods are nearly straight, round, meaty, medium dark-green, and stringless at all stages. The seed are white.

Blue Lake 231 is a standard variety for a main crop. The plants are vigorous and very productive and resistant to common bean mosaic and some

TABLE 1.-Harvesting dates and malurily at harvest of 5 pole-bean varielies planted at the Isabela Subsiation, April 21, 1959

\begin{tabular}{l|c|c}
\hline \multicolumn{1}{c|}{ Varicty } & Harvest dates & $\begin{array}{c}\text { Days of maturity at first } \\
\text { harvest }\end{array}$ \\
\hline Blue Lake 231 & June 10, 16, 23, 26, July 2 & 61 \\
Florigreen & June 8, 16, 23, 26, July 2 & 59 \\
Blue Lake 92 & June 10, 16, 23, 26, July 2 & 61 \\
Kentucky 191 & June 8, 16, 23, 26, July 2 & 59 \\
Blue Lake 228 & June 10,16, 23, 26, July 2 & 61 \\
\hline
\end{tabular}

TABLE 2.-T'otal and mean yields of 5-pole-bean varieties planted at the Isabela Substation, A pril 21, 1959

\begin{tabular}{c|c|c|c}
\hline Treatments & $\begin{array}{c}\text { Total yield per } \\
\text { plot }\end{array}$ & $\begin{array}{c}\text { Mean yields per } \\
\text { plot }\end{array}$ & $\begin{array}{c}\text { Calculated production } \\
\text { per acre }\end{array}$ \\
\cline { 2 - 3 } & Pounds & Pounds & Tons \\
Blue Jake 231 & 59.85 & 11.97 & 8.14 \\
Florigreen & 51.00 & 10.20 & 6.93 \\
Blue Lake 92 & 42.20 & 8.44 & 5.74 \\
Kentucky 191 & 37.50 & 7.50 & 5.09 \\
Blue Lake 228 & 36.35 & 7.27 & 4.94 \\
\hline
\end{tabular}

strains of bean rust. The pods are very dark-green, straight, fleshy, nearly round, and stringless at all stages. The seed are white ${ }^{3}$.

The experiment was planted at the Isabela Substation on April 21, 1959, and the experimental design used was a $5 \times 5$ latin square. Each plot consisted of two rows, 4 feet apart and 20 feet long, making a plot size of one two-hundred and seventy-second of an acre. In each row 10 hills were planted 2 feet apart, with 2 plants per hill. A 9-10-5 fertilizer at 800 pounds per acre was applied to the planting.

The pods were harvested at the best edible and marketable stage. A total of five pickings was made of each variety.

${ }^{3}$ The seed were obtained from Associated Seed Growers, Inc., New Haven, Conn. 


\section{EXPERIMENTAL RESULTS AND DISCUSSION}

The results of this trial are presented in tables 1 and 2 .

The standard error and least differences required for significance between means in table 2 are shown in the following tabulation:

\begin{tabular}{lcc}
\multicolumn{1}{c}{ Ilem } & 5 percent & 1 percent \\
Difference between highest and lowest & 4.25 & 5.51 \\
Difference between highest and 2nd lowest & 3.96 & 5.19 \\
Difference between highest and 3d lowest & 3.56 & 4.75 \\
Difference between highest and 4th lowest & 2.91 & 4.07
\end{tabular}

The yield of variety Blue Lake 231 was significantly higher at the 5-percent level than the yields of Blue Lake 228 and Kentucky 191. There were no significant differences between the yields of Blue Lake 231 and Blue Lake 92 and Florigreen (8). This means that variety Blue Lake 231 proved to be not only good in quality and other desirable characteristics, but also the highest yielding among the pole beans tested. Variety Blue Lake ranks among the best in the State of Oregon, where the average production of pole beans is from 7 to 8 tons per acre. Varieties Blue Lake 231 and Florigreen produced 8.14 and 6.93 tons of beans per acre (4), respectively, in this experiment. The yields obtained with varieties Blue Lake 231 and Florigreen compare favorably with the ones obtained in Oregon where yield of beans per acre is generally high. Field observations on this trial showed that variety Kentucky 191 is susceptible to mosaic disease, making it undesirable for our breeding program.

\section{SUMMARY}

Of five pole-bean varieties tested Blue Lake 231 and Florigreen are considered to be best suited for use in our proposed snap bean breeding program, both for their good quality and other desirable characteristics, and in the case of Blue Lake 231, also for its superiority in yield to the other pole beans tested. The above varieties produced 8.14 and 6.93 tons of beans per acre, respectively, both of them being highly productive under our conditions. Varieties Blue Lake 92, Kentucky 191, and Blue Lake 228 were also included in the experiments.

\section{RESUMEN}

De las cinco variedades de habichuelas trepadoras que se probaron, la variedad Blue Lake 231 fué la mejor, no solamente por su buena calidad, sino también por su superioridad en rendimiento al compararse con las demás variedades. Las producciones de las variedades Blue Lake 231 y Florigreen fueron 8.14 y 6.93 toneladas, respectivamente, lo cual es alto 
34 JOURNAL OF AGRICULTURE OF UNIVERSITY OF PUERTO RICO

para cualquier lugar. Las variedades Blue Lake 92, Kentucky 191, y Blue Lake 228 fueron también incluídas en este experimento.

\section{LITERATURE CITED}

1. P. R. External Trades Statistics, Junta de Planes, 1957-58.

2. Asgrow Export Corp., A Descriptive Catalog of Vegetables, No. 19.

3. Walter, J. M., and Lorz, A. P., Florigreen, A Disease-Resistant Pole Bean, Circ. S-92, Fla. Ag. Exp. Sta., 1956.

4. Zaumeyer, W. J., Snap Beans for Marketing, Canning and Freezing, Farmer's Bul. 1915, U.S.D.A. (Rev.) Sept. 1954. 